\title{
Hepatic mRNA expression for genes related to somatotropic axis, glucose and lipid metabolisms, and inflammatory response of periparturient dairy cows treated with recombinant bovine somatotropin
}

\author{
P. R. B. Silva, ${ }^{*}$ W. J. Weber, ${ }^{*}$ B. A. Crooker, ${ }^{*}$ R. J. Collier, $†$ W. W. Thatcher, $\ddagger$ and R. C. Chebel ${ }^{*} \ddagger \S^{1}$ \\ ${ }^{*}$ Department of Animal Science, University of Minnesota, Saint Paul 55108 \\ †School of Animal and Comparative Biomedical Sciences, The University of Arizona, Tucson 85721 \\ ‡Department of Animal Sciences, and \\ §Department of Large Animal Clinical Sciences, University of Florida, Gainesville 32608
}

\section{ABSTRACT}

Objectives of this experiment were to evaluate the effects of recombinant bovine somatotropin (rbST) treatment of periparturient dairy cows on hepatic mRNA expression for genes related to the somatotropic axis, insulin, glucose, and lipid metabolism, inflammation, and oxidative stress. Holstein cows were enrolled in the experiment at $253 \pm 3 \mathrm{~d}$ of gestation and assigned to 1 of 3 treatments: untreated control $(\mathrm{n}=53), 87.5 \mathrm{mg}$ of $\operatorname{rbST}(\mathrm{n}=56 ; \operatorname{rbST} 87.5)$, and $125 \mathrm{mg}$ of $\operatorname{rbST}(\mathrm{n}=57$; rbST125). Cows in the rbST87.5 and rbST125 treatments received weekly injections of rbST from -21 to $28 \mathrm{~d}$ relative to calving. A subsample of cows (control $=20, \operatorname{rbST} 87.5=20, \operatorname{rbST} 125=20$ ) was randomly selected for collection of liver samples according to expected calving date, BCS, and previous lactation 305-d mature equivalent milk yield. Only cows that had liver sampled at $-21 \pm 3,-7 \pm 3$, and $7 \pm 3$ d relative to calving were used in the current experiment. Blood, sampled weekly from -28 to 21 d relative to calving, was used to determine the concentrations of growth hormone, insulin-like growth factor 1, insulin, cortisol, fatty acids, $\beta$-hydroxybutyrate, glucose, haptoglobin, and tumor necrosis factor- $\alpha$. Liver samples were used to determine hepatic mRNA expression of 50 genes. Treatment with rbST increased growth hormone concentrations during the postpartum period (control = $9.0 \pm 0.7, \operatorname{rbST} 87.5=15.3 \pm 1.0, \operatorname{rbST} 125=18.5 \pm$ $1.3 \mathrm{ng} / \mathrm{mL}$ ) and increased insulin-like growth factor 1 concentrations during the prepartum period (control $=$ $107.4 \pm 7.2, \operatorname{rbST} 87.5=126.9 \pm 6.6, \operatorname{rbST} 125=139.4$ $\pm 6.9 \mathrm{ng} / \mathrm{mL}$ ). Control cows had greater postpartum concentrations of $\beta$-hydroxybutyrate $($ control $=776.4$ $\pm 64.0, \operatorname{rbST} 87.5=628.4 \pm 59.7, \operatorname{rbST} 125=595.4$ $\pm 60.9 \mu \mathrm{mol} / \mathrm{L})$ than $\mathrm{rbST}$ cows. The $\mathrm{rbST} 87.5$ and

Received October 10, 2016.

Accepted November 13, 2016.

${ }^{1}$ Corresponding author: rcchebel@ufl.edu
rbST125 treatments upregulated the hepatic mRNA expression for somatotropic axis genes (GHR, GHR1A, IGF1, IGFBP3, and SOCS2) on d -7 relative to calving and upregulated the mRNA expression for SOCS2 on $\mathrm{d} 7$. On $\mathrm{d}-7, \operatorname{rbST} 87.5$ and rbST125 treatments increased mRNA expression for genes involved in hepatic lipid transport (ANGPTL4, APOA5, APOB100, and $S C A R B 1$ ) and downregulated mRNA expression for PPARD, which is involved in lipid storage. On $\mathrm{d}$ 7 , rbST tended to upregulate the mRNA expression for genes involved in gluconeogenesis (PCK1) and fatty acid $\beta$-oxidation (ACOX1), and downregulated the mRNA expression for genes involved in inflammation (TNFRSF1A, ICAM1, CXCL1, MYD88, HIF1A, $I L 1 R N, N F K B I A$, and SOCS3) and oxidative stress $(X B P 1)$. Administration of rbST during the periparturient period may improve liver function and health by increasing hepatic capacity for gluconeogenesis and lipid transport and by reducing inflammation and oxidative stress.

Key words: periparturient cows, recombinant bovine somatotropin, hepatic gene expression

\section{INTRODUCTION}

The liver performs essential functions in the body by uniquely expressing genes encoding proteins involved in glucose, lipid, and protein metabolism, ketogenesis, immune function, detoxification, hormone catabolism, vitamin and mineral metabolism, and a variety of other functions (Donkin, 2012). Postpartum cow health is closely associated with the capacity of the liver to cope with the changes in nutrient supply and shifting metabolic demands that accompany the initiation of lactation (Drackley et al., 2001). In periparturient dairy cows, the liver has an important role in metabolic regulation and control of the somatotropic axis to successfully adapt to the negative energy balance (NEB; Grummer et al., 2004). During NEB the expression of growth hormone (GH) 1- $\alpha$ receptors (GHR1A) by 
the liver is downregulated to decrease IGF-1 synthesis and its inhibitory effects on synthesis and secretion of GH (Bauman, 2000). Therefore, GH concentrations are increased in periods of NEB, such as the periparturient period, to favor nutrient partitioning for lactogenesis (Bell and Bauman, 1997). The pivotal role of GH in nutrient partitioning includes major alterations in metabolism of carbohydrates and lipids (Lupu et al., 2001). In adipose tissue, GH acts to facilitate lipolysis, increase insulin resistance to reduce glucose uptake and oxidation, and to decrease lipid synthesis (Boyd and Bauman, 1989). In the liver, GH increases gluconeogenesis (Cohick et al., 1989) through the regulation of enzymes, such as phosphoenolpyruvate carboxykinase (PCK), suppression of insulin's inhibitory effect on gluconeogenesis (Velez and Donkin, 2004), and increased hepatic fatty acid oxidation to $\mathrm{CO}_{2}$ (Pocius and Hertlein, 1986).

From late gestation to early lactation, insulin resistance and GH-induced lipolysis cause a marked increase in fatty acids concentration and influx into the liver, which experiences a pronounced metabolic stress to maintain homeostasis (Drackley et al., 2001). The liver takes up approximately one-third of the whole body fatty acid flux, and this often exceeds its oxidation capacity, increasing the risk of liver lipidosis and ketosis (Drackley et al., 2001). During the peripartum period the liver is exposed to a variety of inflammatory factors, such as LPS, proinflammatory cytokines, and reactive oxygen species. These inflammatory factors are increased during the periparturient period due to alterations in gastrointestinal physiology, associated with changes in feed intake and composition, and episodes of infectious (e.g., metritis and mastitis) and gastrointestinal (e.g., SARA and displacement of the abomasum) diseases (Plaizier et al., 2008; Vels et al., 2009). Consequently, periparturient cows may present inflammation of the liver, which may induce an acute phase response (Vels et al., 2009), metabolic disorders, and unfold protein response to oxidative stress (Gessner et al., 2014) that collectively result in impaired liver function.

Treatment of lactating dairy cows with recombinant bovine somatotropin (rbST) increased liver gluconeogenesis, suppressed insulin's inhibitory effect on gluconeogenesis (Peel and Bauman, 1987), and increased complete oxidation of fatty acids in bovine liver slices (Pocius and Hertlein, 1986), which are expected to improve metabolic parameters. Effects of rbST treatment of periparturient cows on metabolic parameters and health are less clear. Whereas treatment of periparturient cows with $500 \mathrm{mg}$ of rbST every $14 \mathrm{~d}$ increased glucose concentration, reduced concentrations of fatty acids and BHB, and increased milk yield according to some (Putnam et al., 1999), it reduced FCM yield ac- cording to others (Eppard et al., 1996). Reduced doses of $\operatorname{rbST}$ (142.8 to $325 \mathrm{mg}$ of rbST every $14 \mathrm{~d}$ ) given to periparturient cows increased IGF-1, insulin, and glucose concentrations but, again, effects on milk yield and health were diverse (Gulay et al., 2003, 2004, 2007; Gohary et al., 2014). In a recent experiment, periparturient Holstein cows were treated with $0,87.5$, and $125 \mathrm{mg}$ of rbST weekly, and those treated with 125 mg had increased IGF-1 concentrations, improved responses associated with innate and adaptive immunity, and reduced BHB concentrations (Silva et al., 2015). Therefore, treatment of periparturient cows with reduced doses of rbST has the potential to significantly affect liver function.

Enhanced knowledge of the processes that regulate liver function and factors that potentiate the capacity of liver to coordinate shifts in nutrient supply and demand by other tissues may lead to significant improvements in peripartum cow management and health. Therefore, the hypotheses of the current experiment were that weekly administration of rbST to peripartum dairy cows would upregulate hepatic mRNA expression for genes related to the somatotropin axis (e.g., GHR, GHR1A, IGF1, and INSR), gluconeogenesis (e.g., G6PC, $P C 1$, and $P C K 1$ ), lipid oxidation and transport (e.g., ACOX1, APOA5, APOB100, and SCARB1), and downregulate the expression of mRNA for genes related to ketogenesis (e.g., HMGCLL1), lipid synthesis and accumulation (e.g., DGAT1 and PPARD), inflammation (e.g., $M Y D 88, N F K B 1, H I F 1$, and $C X C L 1$ ), and oxidative stress (e.g., XBP1). The objectives of the current experiment were to evaluate the effects of peripartum rbST treatment of dairy cows on hepatic mRNA expression for genes related to the somatotropic axis, glucose and lipid metabolisms, inflammation, and oxidative stress.

\section{MATERIALS AND METHODS}

\section{Animals, Enrollment, and Treatments}

All animal procedures conducted during this experiment were approved by the Institutional Animal Care and Use Committee from the University of Minnesota (protocol \#1306-30734A). Cows used in the current experiment are a subgroup of cows used in an experiment that evaluated the effects of rbST treatment during the periparturient period on immune parameters (Silva et al., 2015). Detailed information regarding facilities, management, and nutrition has been previously described (Silva et al., 2015).

Multiparous Holstein cows (lactation $=1$ to 6 ) from a commercial freestall herd located in northwest Wisconsin, with BCS 3.75 to 4.75 (Ferguson et al., 1994) and 
locomotion score 1 and 2 (Sprecher et al., 1997), were enrolled in the experiment at $253 \pm 3 \mathrm{~d}$ of gestation. At enrollment, cows were scored for body condition (1 $=$ emaciated and $5=$ obese; 0.25 -unit increments) and locomotion $(1=$ normal locomotion and $5=$ severely lame), and BW was estimated using a Holstein dairy cow weigh tape (The Coburn Company Inc., Whitewater, WI). Cows were balanced for lactation number, BCS, BW, previous lactation 305-d mature equivalent milk yield, and previous lactation interval from calving to conception. Cows were assigned randomly to 1 of 3 treatments: untreated control $(\mathrm{n}=53), 87.5 \mathrm{mg}$ of $\operatorname{rbST}(\mathbf{r b S T} 87.5 ; \mathrm{n}=56)$, and $125 \mathrm{mg}$ of $\mathrm{rbST}$ (rbST125; $\mathrm{n}=57)$, which were administered every $7 \mathrm{~d}$ from -21 to $28 \mathrm{~d}$ relative to calving. Treatments doses of $\mathrm{rbST}$ were prepared ( 6 to $12 \mathrm{~h}$ before treatment) by dispensing the contents of commercially available syringes of rbST (Posilac, sometribove zinc suspension for injection; Elanco Animal Health, Greenfield, IN) into sterile containers and aspirating the appropriate volume into sterile $1-\mathrm{mL}$ tuberculin syringes to reach 87.5 and $125 \mathrm{mg}$ of rbST. Treatments were administered subcutaneously in the neck area using 16-gauge and 1.6-cm-long hypodermic needles. A subsample of cows $($ control $=20, \operatorname{rbST} 87.5=20, \operatorname{rbST} 125=20)$ was selected for collection of liver samples according to expected calving date and after balancing for BCS and previous lactation 305-d mature-equivalent milk yield. Only data from cows that had liver samples collected at $-21 \pm 3,-7 \pm 3$, and $7 \pm 3 \mathrm{~d}$ relative to calving are reported herein.

\section{Milk Yield and BCS}

Cows were milked thrice daily at both facilities, but milk yield was not measured in the first 21 DIM because the transition cow facility did not have the capability to do so. Daily milk yield was recorded for individual cows (Afimilk Ltd., Kibbutz Afikim, Israel) starting at approximately 22 DIM and recorded on DairyComp305 software (Valley Ag. Software, Tulare, CA). Beginning between 55 to $50 \mathrm{~d}$ postpartum, all cows received 500 $\mathrm{mg}$ of $\mathrm{rbST}$ (Posilac, sometribove zinc suspension; Elanco Animal Health) every $11 \mathrm{~d}$ through 220 to 225 $\mathrm{d}$ of gestation. Body condition was scored weekly from -28 to $28 \mathrm{~d}$ relative to calving.

\section{Hormones, Metabolites, and Indicators of Inflammation Measurements}

Cows that had liver samples collected $(\mathrm{n}=32)$ also had blood sampled weekly from -28 to $21 \mathrm{~d}$ relative to calving to determine concentrations of GH, IGF-1, insulin, cortisol, fatty acids, BHB, glucose, haptoglobin, and tumor necrosis factor- $\alpha$ (TNF- $\alpha$ ). During feeding, when cows were restrained in self-locking headlocks, blood samples were collected from the coccygeal vein or artery using 22-gauge and 2.5-cm-long needles into evacuated tubes without anticoagulants and evacuated tubes containing $\mathrm{K}_{2}$ EDTA (Becton Dickinson Vacutainer Systems, Franklin Lakes, NJ). Tubes were placed in ice until centrifugation $\left(1,200 \times g\right.$ for 15 min at $\left.4^{\circ} \mathrm{C}\right)$ for serum or plasma separation within $8 \mathrm{~h}$ after blood samples were collected. Serum and plasma were aliquoted into microcentrifuge tubes and stored at $-32^{\circ} \mathrm{C}$ until analysis.

Serum GH and total IGF-1 concentrations were determined in triplicate using a modified RIA (Lalman et al., 2000); the intra- and interassay coefficients of variation (CV) for the GH and IGF-1 assays were lower than $5 \%$. Serum insulin concentrations were determined by a commercial bovine ELISA kit (Mercodia Bovine Insulin ELISA; Mercodia AB, Uppsala, Sweden); the intraand interassay CV were 8 and $5 \%$, respectively. Serum cortisol was measured by a solid phase RIA using a commercially available kit (Coat-A-Count Cortisol; Siemens Medical Solutions Diagnostics, Los Angeles, CA); the intra- and interassay CV for cortisol were 7 and $6 \%$, respectively. Plasma concentrations of fatty acids were determined using a colorimetric assay (Wako Chemicals USA, Richmond, VA; Ballou et al., 2009) and plasma concentrations of BHB were determined enzymatically (Ranbut, Randox Laboratories, Antrim, UK; Ballou et al., 2009). The intra-assay CV were 7 and $11 \%$ for the fatty acid and BHB assays, respectively; the interassay $\mathrm{CV}$ were 4 and $8 \%$ for the fatty acid and BHB assays, respectively. Plasma glucose concentrations were determined by enzymatic reaction (Stanbio Laboratory, Boerne, TX); the intra- and interassay CV were 4 and $3 \%$, respectively. Plasma haptoglobin concentrations were determined by a colorimetric procedure (Hulbert et al., 2011); the intra- and interassay CV were 4 and $3 \%$, respectively. Concentrations of plasma TNF- $\alpha$ were determined by ELISA using a protocol described and validated for bovine plasma (Farney et al., 2011); the intra- and interassay CV were 5 and $3 \%$, respectively.

\section{Liver Samples and mRNA Extraction and Quality Assessment}

Liver tissue samples were collected $-21 \pm 3,-7 \pm 3$, and $7 \pm 3 \mathrm{~d}$ relative to calving to determine mRNA expression of 50 genes. Eight genes were internal control candidates and 42 genes were genes of interest related to the somatotropic axis, metabolism of glucose and lipids, inflammation, and oxidative stress (Table 1).

Percutaneous needle (Bard Magnum, Covington, GA) technique was performed to obtain the liver samples 
Table 1. Genes and accession numbers according to National Center for Biotechnology Information (NCBI)

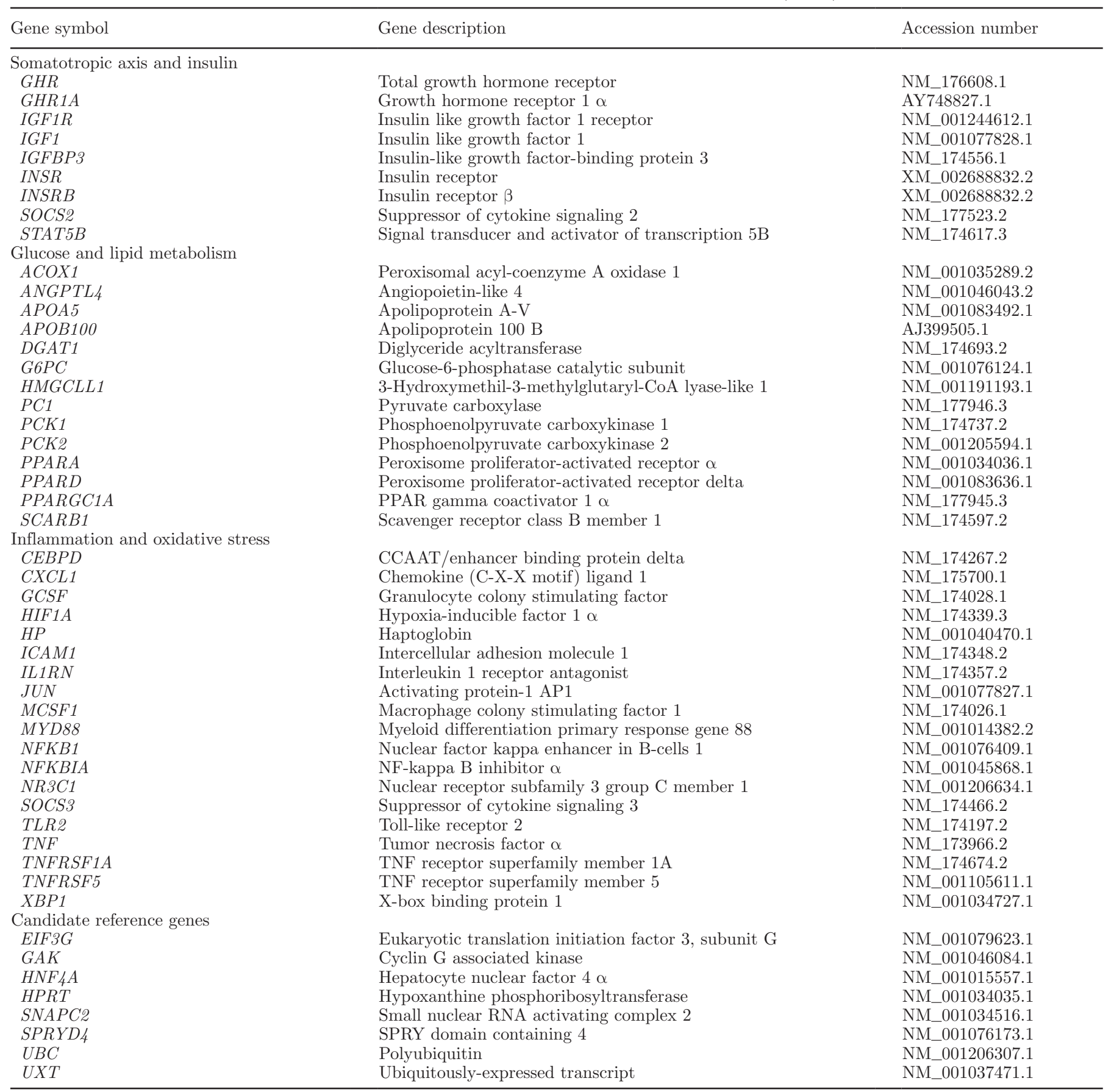

(Sigl et al., 2013). Briefly, an area of $15 \times 15 \mathrm{~cm}$ on the right side of the cow was shaved, washed, and degreased with $70 \%$ ethanol and subsequently disinfected with an iodine solution (Povidone-Iodine Solution USP 10\%, Ricca Chemical Company, Arlington, TX). Local anesthetic $(10 \mathrm{~mL}$; lidocaine hydrochloride injection $2 \%$, Vedco Inc., Saint Joseph, MO) was used to desensitize skin, subcutaneous tissue, and intercostal muscle. An incision (approximately $2 \mathrm{~cm}$ long) was made through the skin at the intersection of an imaginary line running from the tuber coxae to the shoulder joint with the 11th and 12th intercostal space. The trocar was inserted through the incision to collect samples from the caudate lobe of the liver. A skin surgical stapler (APPOSE ULC Skin Staplers, New Haven, CT) was used to close the incision. Staples were removed after 
2 wk before subsequent liver sample collection when the incision was healed. Approximately $200 \mathrm{mg}$ of liver tissue were obtained from each sample collection and directly transferred into sterile Eppendorf tubes (Sigma-Aldrich, St. Louis, MO) that were immediately frozen in liquid nitrogen and stored at $-80^{\circ} \mathrm{C}$ until mRNA extraction.

The mRNA was extracted from $50 \mathrm{mg}$ of liver tissue using RNeasy mini kit columns (Qiagen, Valencia, CA). Total RNA restrained on the columns after extraction protocol was eluted with $50 \mu \mathrm{L}$ of sterile RNaseDNase-free water (Qiagen). Quantity and purity of the extracted RNA were estimated using a NanoDrop spectrophotometer (ND-2000, NanoDrop Technologies Inc., Wilmington, DE) at 230, 260, and $280 \mathrm{~nm}$ absorbance waves. Purity was accepted when the $280 / 260$ and $260 / 230$ absorbance ratios were $\geq 1.90$ and 1.80 , respectively. The ratios obtained in the samples ranged from 1.97 to 2.08 and 1.77 to 2.28 for the $280 / 260$ and 260/230 ratios, respectively. A portion of each RNA sample was diluted in RNase-/DNase-free water (Qiagen) to achieve a consistent sample concentration of $100 \mathrm{ng} / \mu \mathrm{L}$.

The integrity of RNA was assessed with the Agilent 2100 Bioanalyzer (Agilent Technologies, Santa Clara, CA) and the Agilent RNA 6000 Nano Kit (Agilent Technologies) according to the manufacturer's protocol. All samples had an RNA integrity number of $>7$.

\section{Gene Expression Analysis, Reference Gene Selection, and Data Normalization}

Hepatic mRNA expression was assessed by single-molecule imaging of targeted mRNA molecules hybridized with color-coded probe pairs and molecular barcodes using the NanoString nCounter System (NanoString Technologies, Seattle, WA). The direct digital readout of each mRNA and its relative abundance was measured in $100 \mathrm{ng}$ of total RNA. The nSolver 2.0 Analysis Software (NanoString Technologies) was used to perform automated quality control (QC) metrics to detect flags on imaging, binding density, linearity, and limit detection of control probes. Imaging and binding density QC were set to detect flags when the percentage of fields of view successfully counted by the digital analyzer scan was less than 75 and binding density was outside the 0.05 to 2.25 range. The positive control linearity and limit of detection QC were set to flag lanes when positive control coefficient of determination values were less than 0.95 and when $0.5 \mathrm{fM}$ detection was $\leq 2$ standard deviations above the mean of the negative controls. No QC flags were detected in the samples.

Eight candidate reference genes (EIF3G, GAK, HNF 4A, HPRT, SNAPC2, SPRYD4, UBC, and UXT;
Table 1) were evaluated for their ability to fulfill 2 criteria: to be stably expressed in the samples and to provide mRNA counts that span the range of mRNA counts of the genes of interest. NormFinder software was used to determine the most stable genes (Andersen et al., 2004). Four genes, HNF $4 A, S P R Y D 4, U B C$, and $U X T$, were the most stable and were used in the data normalization process.

To account for slight differences in hybridization and purification efficiency, data were normalized from each sample to its positive controls and selected reference genes using the nSolver 2.0 Analysis Software (NanoString Technologies). The positive hybridization controls are RNA control transcript sequences that are not homologous to any known organism and generate consistent results in gene expression analyses (NanoString Technologies). Positive controls allowed for the correction of sample-to-sample variation due to assay-specific factors such as differences in amount of input material or reagents. The negative correction was used to subtract the background noise from the positively corrected data using counts of 6 negative controls (sequence blank tags) by subtracting the negative controls geometric mean +2 standard deviations. The normalization procedure consisted of the adjustment of all mRNA counts data to normalization factors generated specifically for each sample based on the geometric means, within and across all samples, of 6 positive controls and selected reference genes counts.

\section{Statistical Analysis}

All statistical analyses were conducted using SAS version 9.4 (SAS/STAT, SAS Inst. Inc., Cary, NC). In all models, cows were used as the experimental unit. Only cows that had a complete set of liver biopsies (n $=32$ ) were included in the statistical analysis.

The assumption of normality of variables and residuals of continuous data were assessed using the UNIVARIATE procedure of SAS and the residual output function of SAS. A natural log or square root transformation was applied to achieve a normal distribution, when necessary, and data were back transformed to original scale for reporting. Continuous data without repeated measurements (i.e., previous 305-d mature equivalent milk yield, previous interval from calving to conception, lactation number, days in the close-up pens, BCS and BW at enrollment, and milk yield) were analyzed by ANOVA using the MIXED procedure of SAS, and treatment was included in the model as the fixed effect. The MIXED procedure of SAS was used to analyze continuous data with repeated measurements (i.e., GH, IGF-1, insulin, cortisol, fatty acid, BHB, glucose, haptoglobin, TNF- $\alpha$, and BCS). For analyses of repeated 
measurements, the repeated statement was used and treatment, time, and the interaction between treatment and time were included in the model as fixed effects. The structure of covariance (auto-regressive, unstructured, or compound symmetry) was chosen according to the Bayesian information criteria. Cow was included as the random effect and cows were nested within treatment. The prepartum and postpartum periods were analyzed separately because of inherent physiological changes that occur during calving. Dichotomous data (i.e., incidence of postpartum diseases) were analyzed by logistic regression using the LOGISTIC procedure of SAS, and 2 by 2 tables were generated using the FREQ procedure of SAS.

An ANOVA was used to analyze the effects of treatment on hepatic mRNA expression at the different time points relative to calving using the GLM procedure of SAS with treatment as a fixed effect. In the model to determine the effect of treatment on hepatic mRNA expression on $\mathrm{d}-7$ relative to calving, hepatic mRNA expression on $\mathrm{d}-21$ relative to calving was used as a covariate. Hepatic mRNA expression on $\mathrm{d} 7$ relative to calving was analyzed separately because of inherent physiological changes that occur during calving.

When the effect of treatment on dependent variables was $P \leq 0.15,2$ orthogonal contrasts were used to compare the effects of treatments: control versus rbST87.5 $+\operatorname{rbST125}$ and rbST87.5 versus rbST125. Statistical significance of the contrast analysis was defined as $P$ $\leq 0.05$ and tendency was defined as $0.05<P \leq 0.10$.

\section{RESULTS}

\section{Descriptive Parameters at Enrollment and Calving}

Twenty-eight cows (control $=10, \operatorname{rbST} 87.5=8$, and rbST125 = 10) had collection of liver samples interrupted and were removed from the experiment for the following reasons: cows calved $<3$ wk after enrollment $(\mathrm{n}=17)$ and cows calved $>3 \mathrm{wk}$ after enrollment $(\mathrm{n}=$ 11). Thirty-two cows remained in the experiment and their data were used in the statistical analysis (control $=10, \operatorname{rbST} 87.5=12$, and $\operatorname{rbST} 125=10)$.

At enrollment, average lactation number (control $=$ $1.9 \pm 0.3, \operatorname{rbST} 87.5=2.1 \pm 0.3, \operatorname{rbST} 125=2.1 \pm 0.3 ;$ $P=0.89)$, BCS (control $=4.0 \pm 0.1, \operatorname{rbST} 87.5=4.0$ $\pm 0.1, \operatorname{rbST} 125=4.1 \pm 0.1 ; P=0.60)$, BW (control $=800.2 \pm 21.4, \operatorname{rbST} 87.5=788.9 \pm 19.5, \operatorname{rbST} 125=$ $796.3 \pm 21.4 \mathrm{~kg} ; P=0.92)$, previous lactation $305-\mathrm{d}$ mature equivalent milk yield (control $=11,545 \pm 640$, $\operatorname{rbST} 87.5=12,901 \pm 585, \operatorname{rbST} 125=12,252 \pm 640 \mathrm{~kg} ;$ $P=0.31$ ), previous lactation interval from calving to conception (control $=166.8 \pm 22.3, \operatorname{rbST} 87.5=150.2$ $\pm 20.4, \operatorname{rbST} 125=163.8 \pm 22.3 \mathrm{~d} ; P=0.84)$, and days of gestation $($ control $=253.3 \pm 0.2, \operatorname{rbST} 87.5=253.4$ $\pm 0.1, \operatorname{rbST} 125=253.2 \pm 0.2 \mathrm{~d} ; P=0.57)$ were not different among treatments. Number of days cows stayed in the close-up pen before calving (control $=27.0 \pm$ $0.7, \operatorname{rbST} 87.5=28.0 \pm 0.7, \operatorname{rbST} 125=27.5 \pm 0.7 \mathrm{~d}$; $P=0.59)$ and percentage of cows calving male calves $($ control $=50.0, \operatorname{rbST} 87.5=41.7, \operatorname{rbST} 125=50.0 \% ; P$ $=0.90)$ were not different among treatments.

\section{Effects of rbST Treatment on Hepatic Gene Expression}

From the 42 genes of interest and 8 internal control genes analyzed (Table 1), only HMGCLL1 and GCSF were not detected. Hepatic mRNA expression on $\mathrm{d}-21$ was not $(P>0.15)$ different among treatments (Table 2; Figures 1 to 3 ) except for the SOCS3 gene, which had $(P=0.02)$ greater expression in rbST cows compared with control cows (Figure 3). Twenty-six genes were modulated by treatment on $\mathrm{d}-7$ or 7 relative to calving (Table 2; Figures 1 to 3).

\section{Effects of rbST Treatment on Somatotropic Axis}

Hepatic expression of mRNA for GHR and GHR1A on $\mathrm{d}-7$ relative to calving tended $(P=0.07)$ to be and was $(P=0.03)$ affected by treatment, respectively. The contrasts demonstrated an upregulation $(P \leq 0.02)$ of mRNA expression for GHR and GHR1A in rbST cows compared with control cows (Figure 1). On d 7 relative to calving, mRNA expression for GHR1A tended $(P=0.08)$ to be affected by treatment because rbST treatment tended $(P=0.06)$ to upregulate mRNA expression for GHR1A compared with control treatment (Figure 1). Although during the prepartum period serum GH concentration was not $(P=0.23)$ affected by treatment, postpartum serum GH concentrations were $(P=0.01)$ affected by treatment as rbST cows had $(P$ $<0.01)$ greater $\mathrm{GH}$ concentrations than control cows (Figure 1).

Hepatic mRNA expression for SOCS2 tended to be affected by treatment on $\mathrm{d}-7(P=0.15)$ and $7(P=$ $0.06)$. On $\mathrm{d}-7 \mathrm{rbST}$ treatment tended $(P=0.09)$ to upregulate SOCS2 expression compared with control, and on d $7 \mathrm{rbST}$ treatment upregulated $(P=0.02)$ mRNA expression for SOCS2 compared with control cows (Figure 1). Although there was a tendency ( $P$ $=0.08)$ for treatment to affect mRNA expression for $I G F 1 R$ on $\mathrm{d}-7$ (Table 2), according to the results of the contrasts there were no differences among control and rbST-treated cows $(P=0.15)$ and between rbST87.5 and rbST125 cows $(P=0.15)$ regarding mRNA expression for IGF1R. The hepatic mRNA expression for $I G F 1 R$ on d 7 was not $(P=0.27)$ affected 


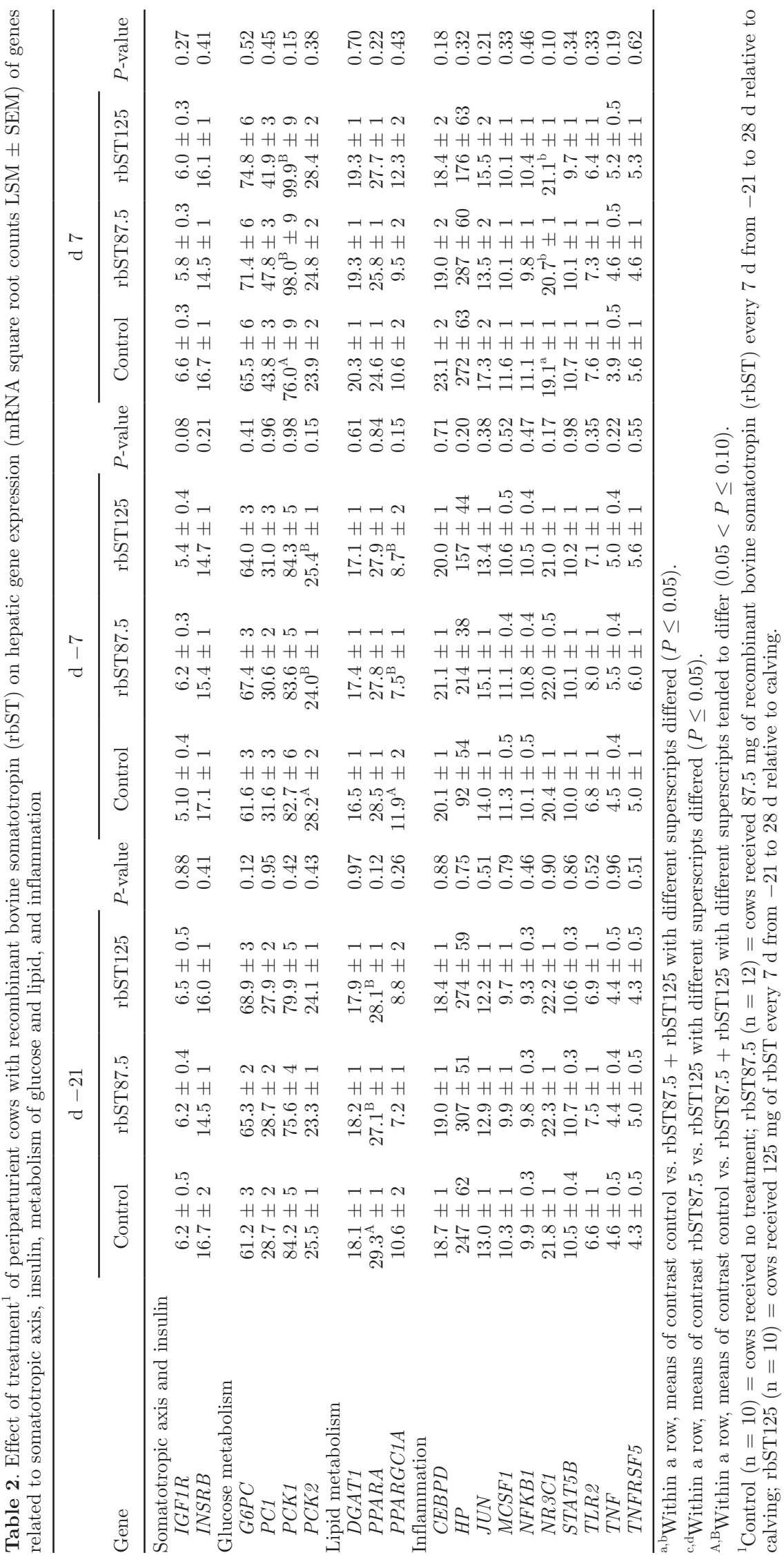


by treatment (Table 2). The hepatic mRNA expression for IGF1 on d -7 was $(P=0.01)$ affected by treatment, as mRNA expression for IGF1 was upregulated $(P<0.01)$ among rbST cows compared with control cows (Figure 1). On d 7, treatment tended $(P=0.10)$ to affect mRNA expression for $I G F 1$ because $\operatorname{rbST} 87.5$ treatment upregulated $(P=0.03)$ mRNA expression for $I G F 1$ compared with the rbST125 treatment (Figure 1). The mRNA expression for IGFBP3 on $\mathrm{d}-7$ tended $(P=0.14)$ to be affected by treatment because rbST treatment tended $(P=0.07)$ to upregulate the expression of mRNA for IGBP3 compared with control.

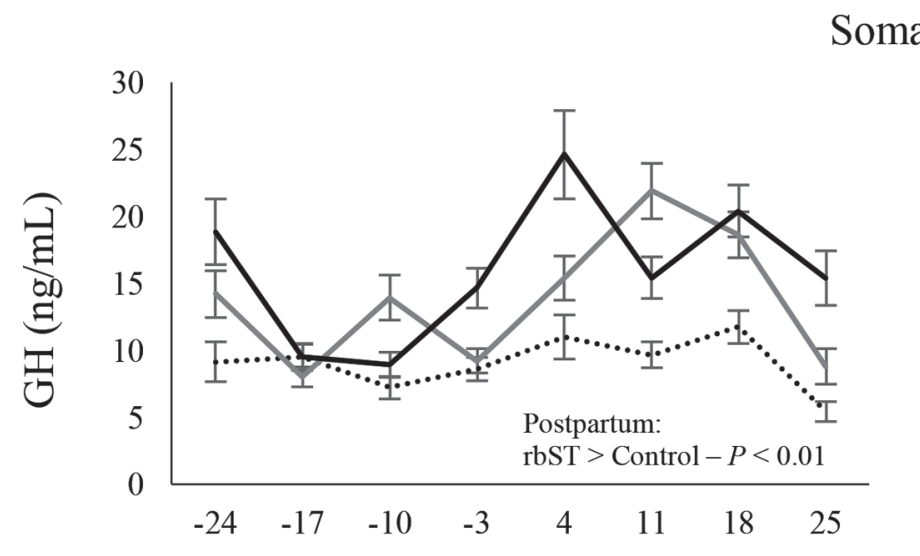

otropic axis
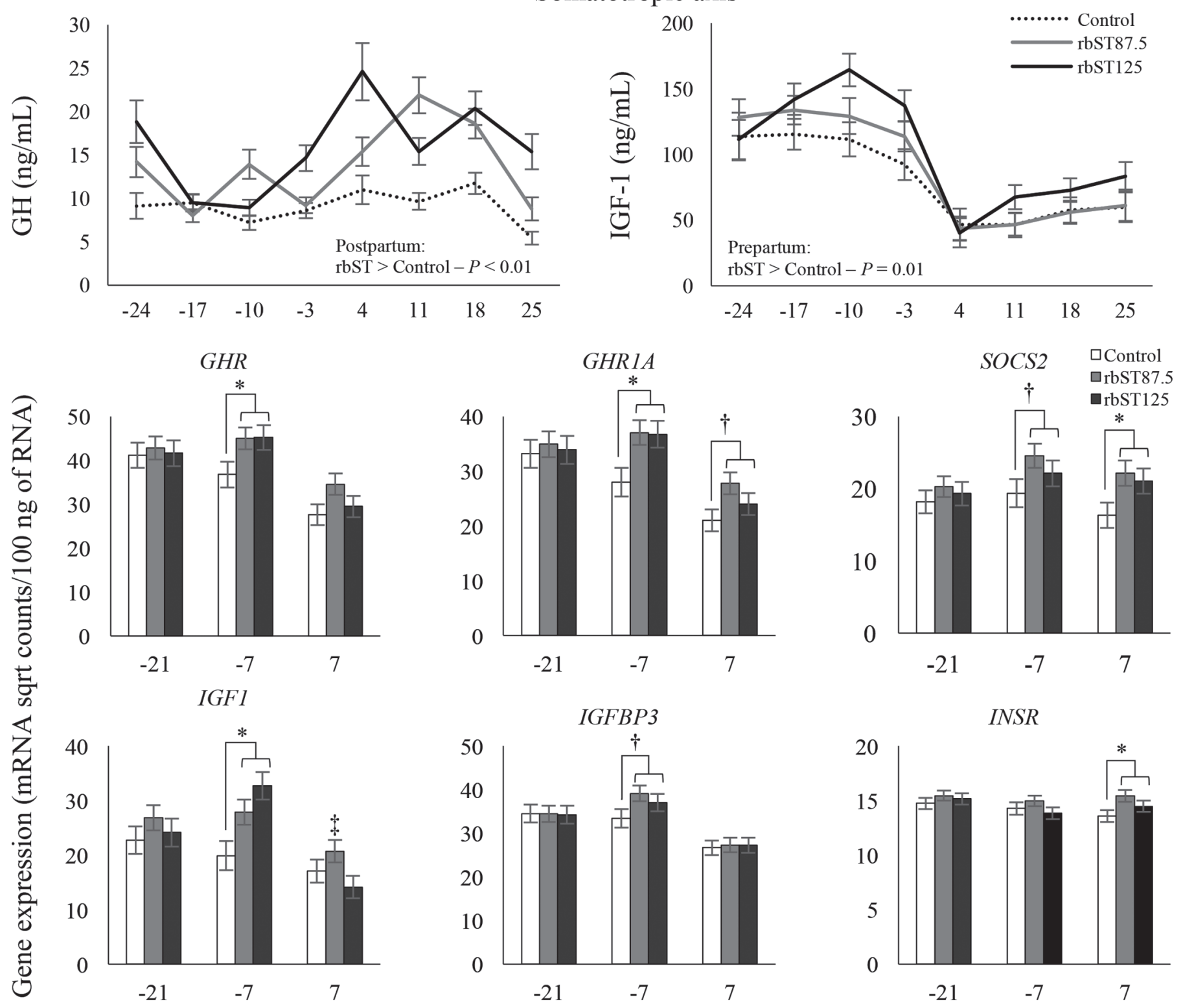

Day relative to calving

Figure 1. Effect of treatment (LSM \pm SEM) of periparturient cows with recombinant bovine somatotropin (rbST) on serum growth hormone $(\mathrm{GH})$ and IGF-1 concentrations and hepatic mRNA expression for genes related to somatotropic axis. Treatments were control $=$ cows received no treatment; rbST87.5 = cows received $87.5 \mathrm{mg}$ of rbST every $7 \mathrm{~d}$ from -21 to $28 \mathrm{~d}$ relative to calving; and rbST125 $=$ cows received $125 \mathrm{mg}$ of rbST every $7 \mathrm{~d}$ from -21 to $28 \mathrm{~d}$ relative to calving. Prepartum GH: treatment $(P=0.23)$, day $(P=0.29)$, and interaction between treatment and day $(P=0.33)$; postpartum GH: treatment $(P=0.01)$, day $(P=0.03)$, and interaction between treatment and day $(P=0.52)$; prepartum IGF-1: treatment $(P=0.01)$, day $(P=0.16)$, and interaction between treatment and day $(P=0.11)$; postpartum IGF-1: treatment $(P=0.39)$, day $(P<0.01)$, and interaction between treatment and day $(P=0.15)$. An asterisk $(*)$ indicates control vs. $\operatorname{rbST} 87.5+\operatorname{rbST} 125$ differed $(P \leq$ $0.05)$; a dagger $(\dagger)$ indicates contrasts control vs. rbST87.5 + rbST125 tended to differ $(0.05<P \leq 0.10)$. 
On d 7, however, treatment did not $(P=0.96)$ affect tions (Figure 1$)$ because rbST treated cows had $(P=$ mRNA expression for IGFBP3 (Figure 1). Treatment affected $(P=0.01)$ prepartum serum IGF-1 concentra-

0.01 ) higher serum IGF-1 concentrations than control cows. Concentrations of IGF-1 during the postpartum

\section{Lipid metabolism}
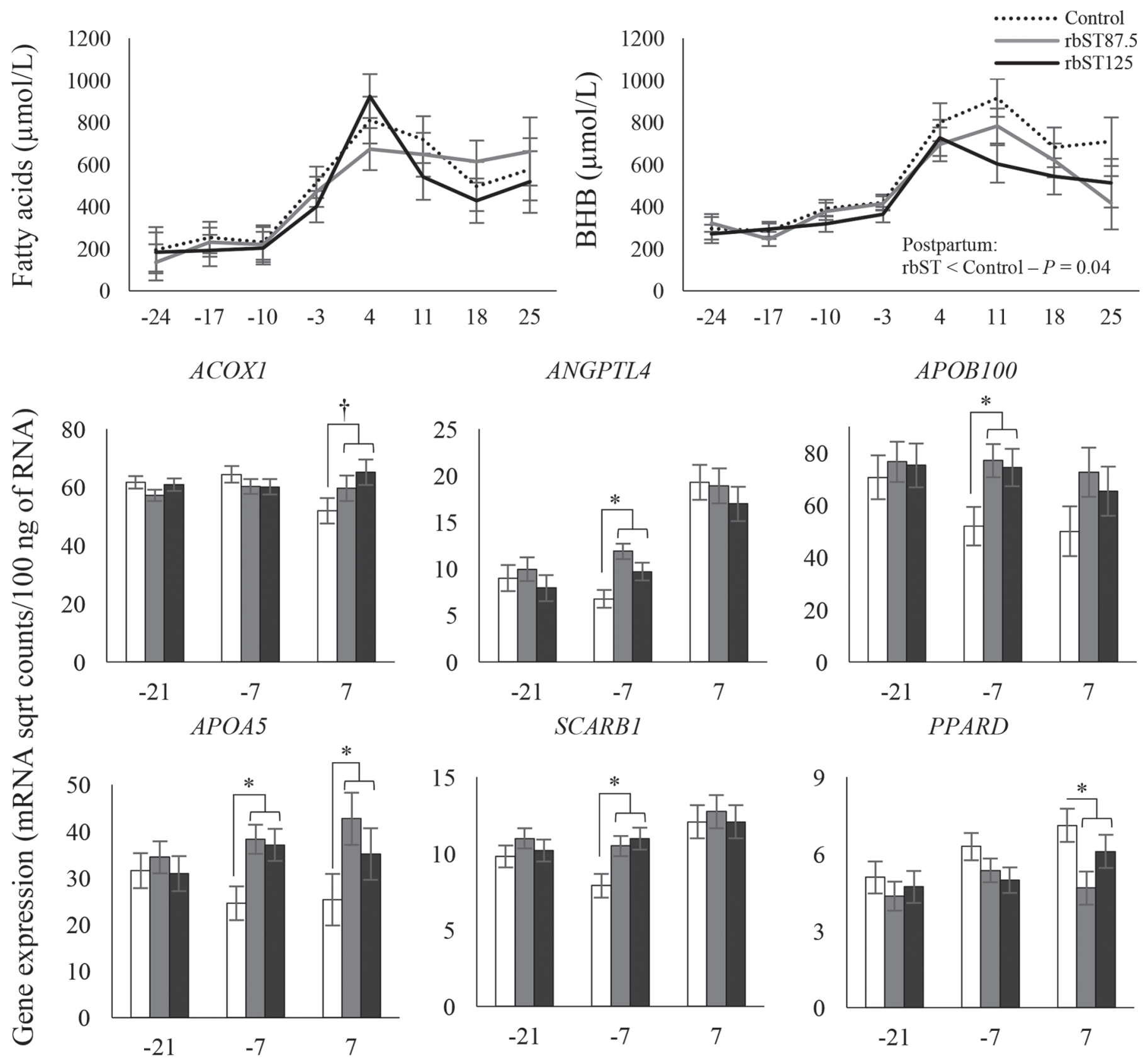

Day relative to calving

Figure 2. Effect of treatment (LSM \pm SEM) of periparturient cows with recombinant bovine somatotropin (rbST) on serum fatty acids and BHB concentrations and hepatic mRNA expression for genes related to lipid metabolism. Treatments were control = cows received no treatment; rbST $87.5=$ cows received $87.5 \mathrm{mg}$ of rbST every $7 \mathrm{~d}$ from -21 to $28 \mathrm{~d}$ relative to calving; and rbST125 = cows received $125 \mathrm{mg}$ of rbST every 7 d from -21 to $28 \mathrm{~d}$ relative to calving. Prepartum fatty acids: treatment $(P=0.84)$, day $(P<0.01)$, and interaction between treatment and day $(P=0.80)$; postpartum fatty acids: treatment $(P=0.59)$, day $(P=0.02)$, and interaction between treatment and day $(P=0.46) ;$ prepartum BHB: treatment $(P=0.57)$, day $(P<0.01)$, and interaction between treatment and day $(P=0.60)$; postpartum BHB: treatment $(P=0.11)$, day $(P=0.02)$, and interaction between treatment and day $(P=0.45)$. An asterisk $(*)$ indicates contrast control vs. rbST87.5 + rbST125 differed $(P \leq 0.05)$; a dagger $(\dagger)$ indicates contrast control vs. rbST87.5 + rbST125 tended to differ $(0.05<P \leq 0.10)$. 


\section{Inflammation and oxidative stress}

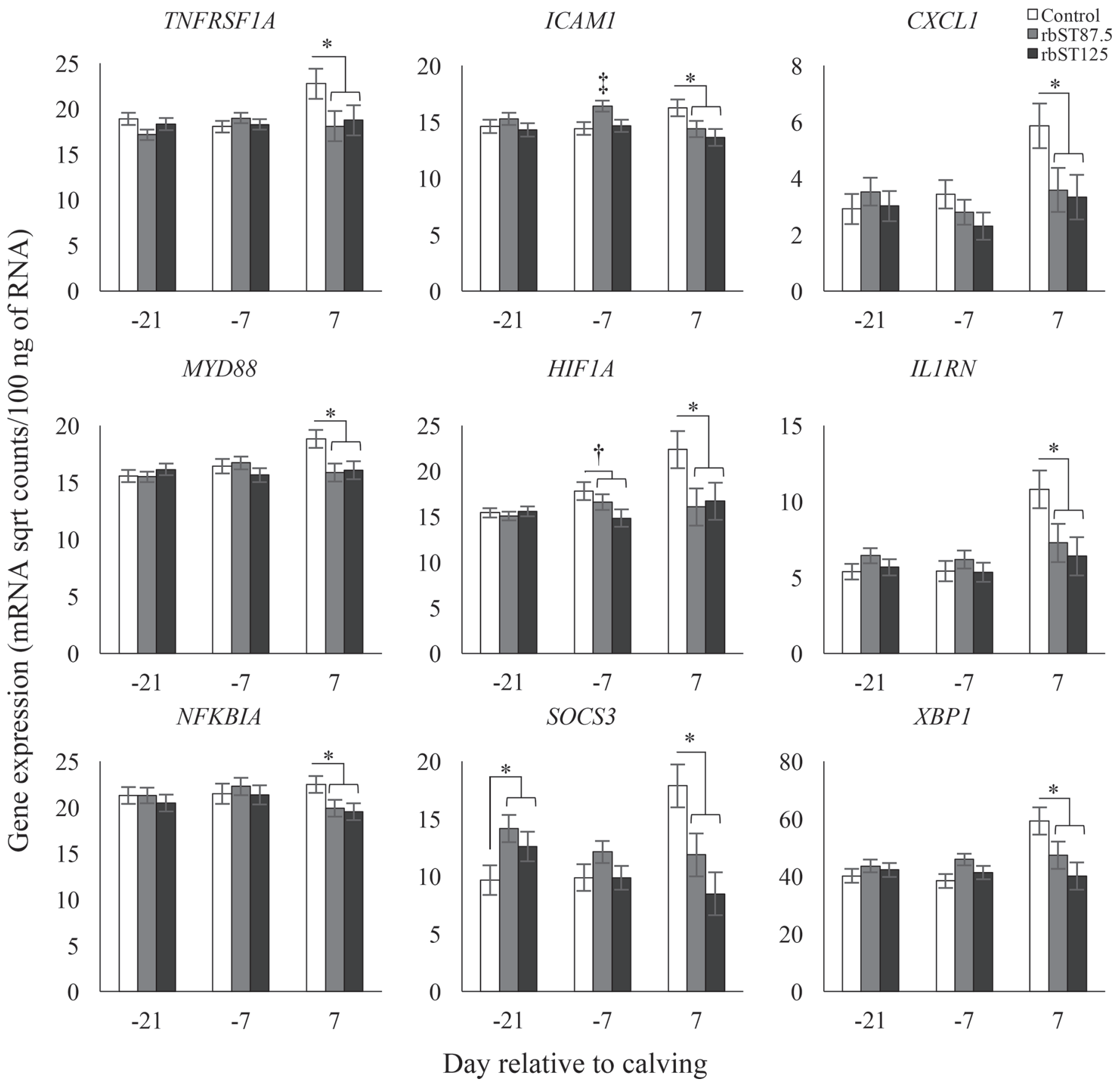

Figure 3. Effect of treatment (LSM \pm SEM) of periparturient cows with recombinant bovine somatotropin (rbST) on hepatic mRNA expression of genes related to inflammatory responses and oxidative stress. Treatments were control $=$ cows received no treatment; rbST87.5 $=$ cows received $87.5 \mathrm{mg}$ of rbST every $7 \mathrm{~d}$ from -21 to $28 \mathrm{~d}$ relative to calving; and rbST125 = cows received $125 \mathrm{mg}$ of rbST every $7 \mathrm{~d}$ from -21 to $28 \mathrm{~d}$ relative to calving. An asterisk $(*)$ indicates contrast control vs. rbST87.5 + rbST125 differed $(P \leq 0.05)$; a dagger $(\dagger)$ indicates contrast control vs. $\operatorname{rbST} 87.5+\operatorname{rbST} 125$ tended to differ $(0.05<P \leq 0.10)$; and double dagger $(\ddagger)$ indicates contrast rbST87.5 vs. rbST125 differed $(P \leq 0.05)$.

period, however, were not $(P=0.39)$ affected by treatment (Figure 1).

There was no effect of treatment on mRNA expression for INSRB on $\mathrm{d}-7$ and 7 relative to calving $(P$ $\geq 0.21$; Table 2). Hepatic mRNA expression for INSR was not affected by treatment on $\mathrm{d}-7(P=0.28)$. On d 7 , treatment tended $(P=0.07)$ to affect mRNA expression for INSR, as rbST treatment upregulated 
Table 3. Effect of treatment (Trt) of periparturient cows with recombinant bovine somatotropin (rbST) on concentrations of insulin, glucose, cortisol, haptoglobin, and tumor necrosis factor- $\alpha$ (LSM \pm SEM)

\begin{tabular}{|c|c|c|c|c|c|c|}
\hline \multirow[b]{2}{*}{ Item } & \multicolumn{3}{|c|}{ Treatment $^{1}$} & \multicolumn{3}{|c|}{$P$-value } \\
\hline & $\begin{array}{c}\text { Control } \\
(\mathrm{n}=10)\end{array}$ & $\begin{array}{c}\operatorname{rbST} 87.5 \\
(\mathrm{n}=12)\end{array}$ & $\begin{array}{l}\mathrm{rbST} 125 \\
(\mathrm{n}=10)\end{array}$ & Trt & Day & Trt $\times$ day \\
\hline \multicolumn{7}{|l|}{ Prepartum } \\
\hline Insulin, ng/mL & $0.95 \pm 0.1$ & $0.98 \pm 0.1$ & $1.03 \pm 0.1$ & 0.89 & $<0.01$ & 0.38 \\
\hline Glucose, mg/dL & $70.4 \pm 3.0$ & $73.5 \pm 2.7$ & $72.7 \pm 2.9$ & 0.73 & 0.26 & 0.11 \\
\hline Cortisol, ng/mL & $3.0 \pm 0.1$ & $5.4 \pm 0.1$ & $5.2 \pm 0.6$ & 0.20 & 0.01 & 0.86 \\
\hline \multicolumn{7}{|l|}{ Postpartum } \\
\hline Insulin, ng/mL & $0.21 \pm 0.05$ & $0.27 \pm 0.04$ & $0.22 \pm 0.04$ & 0.52 & 0.21 & 0.53 \\
\hline Glucose, $\mathrm{mg} / \mathrm{dL}$ & $63.9 \pm 2.6$ & $67.0 \pm 2.4$ & $63.7 \pm 2.5$ & 0.57 & 0.91 & 0.63 \\
\hline Cortisol, $\mathrm{ng} / \mathrm{mL}$ & $2.7 \pm 0.1$ & $3.8 \pm 0.1$ & $2.6 \pm 0.1$ & 0.56 & $<0.01$ & 0.49 \\
\hline Haptoglobin, OD × 100 & $1.8 \pm 0.4$ & $2.5 \pm 0.4$ & $1.3 \pm 0.4$ & 0.19 & 0.03 & 0.74 \\
\hline Tumor necrosis factor- $\alpha, \log$ & $2.8 \pm 0.1$ & $2.9 \pm 0.1$ & $2.7 \pm 0.1$ & 0.36 & 0.49 & 0.57 \\
\hline
\end{tabular}

${ }^{a, b}$ Within a row, means of contrast control vs. rbST87.5 + rbST125 and rbST87.5 vs. rbST125 with different superscripts differed $(P \leq 0.05)$ when prepartum and postpartum periods were analyzed separately.

${ }^{1}$ Control $=$ cows received no treatment; rbST87.5 = cows received $87.5 \mathrm{mg}$ of rbST every $7 \mathrm{~d}$ from -21 to $28 \mathrm{~d}$ relative to calving; rbST125 = cows received $125 \mathrm{mg}$ of rbST every $7 \mathrm{~d}$ from -21 to $28 \mathrm{~d}$ relative to calving.

${ }^{2} \mathrm{OD}=$ optical density.

$(P=0.05)$ mRNA for INSR compared with control (Figure 1). Serum insulin concentrations, however, were not different among treatments during the prepartum or postpartum periods $(P \geq 0.52$; Table 3$)$.

\section{Effects of rbST Treatment on Glucose and Lipid Metabolism}

Treatment did not affect hepatic mRNA expression for the genes $G 6 P C$ and $P C 1$ on d -7 and 7 relative to calving $(P \geq 0.41$; Table 2$)$. Hepatic mRNA expression for $P C K 1$ was not affected $(P=0.98)$ by treatment on $\mathrm{d}-7$. On $\mathrm{d} 7$, there was a tendency $(P=0.15)$ for treatment to affect mRNA expression for PCK1 because rbST treatment tended $(P=0.06)$ to upregulate mRNA expression for PCK1 compared with control (Table 2). Hepatic mRNA expression for PCK2 tended $(P=0.15)$ to be affected by treatment on $\mathrm{d}-7$ because rbST treatment tended $(P=0.07)$ to downregulate mRNA expression for $P C K 2$ compared with control, but treatment did not $(P=0.38)$ affect mRNA expression for PCK2 on d 7 (Table 2; Figure 2). Surprisingly, treatment did not affect prepartum $(P=0.73)$ and postpartum $(P=0.57)$ glucose plasma concentrations (Table 3).

Hepatic mRNA expression for ACOX1 was not $(P$ $=0.47$ ) affected by treatment on $\mathrm{d}-7$. On $\mathrm{d} 7$, treatment tended $(P=0.12)$ to affect mRNA expression for $A C O X 1$ because rbST treatment tended $(P=0.06)$ to upregulate its expression compared with control (Figure 2). Hepatic mRNA expression for ANGPTL4, $A P O A 5, A P O B 100(P \leq 0.05)$, and SCARB1 $(P=$
0.02 ) were affected by treatment on $\mathrm{d}-7$, as $\mathrm{rbST}$ treatment upregulated $(P<0.03)$ mRNA expression for these genes compared with control (Figure 2). On d 7, treatment did not $(P \geq 0.25)$ affect mRNA expressions for ANGPTL4, APOB100, and SCARB1, but tended $(P=0.10)$ to affect mRNA expression for APOA5. Treatment with rbST upregulated $(P=0.05)$ mRNA expression for APOA5 compared with control (Figure 2). Hepatic mRNA expression for PPARD was not $(P=0.20)$ different among treatments on $\mathrm{d}$ -7 . Expression of mRNA for PPARD on $\mathrm{d} 7$ was $(P$ $=0.04$ ) affected by treatment because rbST treatment downregulated $(P=0.04)$ mRNA expression for PPARD compared with control (Figure 2). Expression of mRNA for PPARGC1A tended $(P=0.15)$ to be affected by treatment on $\mathrm{d}-7$ because rbST treatment tended $(P=0.06)$ to downregulate mRNA expression for PPARGC1A compared with control. Expression of mRNA for PPARGC1A on d 7, however, was not $(P=$ 0.43 ) affected by treatment (Table 2). Treatment had no effect on mRNA expression for DGAT1 and PPARA on $\mathrm{d}-7$ and 7 relative to calving ( $P \geq 0.22$; Table 2$)$. Plasma concentrations of fatty acids were not affected by treatment during the prepartum $(P=0.84)$ and postpartum $(P=0.59)$ periods (Table 3 and Figure $2)$. Although treatment did not $(P=0.57)$ affect BHB concentration during the prepartum period, there was a tendency $(P=0.11)$ for BHB concentration during the postpartum period to be affected by treatment, as control cows had $(P=0.04)$ higher plasma BHB concentrations than rbST-treated cows (Table 3 and Figure 2). 


\section{Effects of rbST Treatment on Inflammation and Oxidative Stress}

Hepatic mRNA expression for TNFRS1A on $\mathrm{d}$ -7 was not $(P=0.52)$ affected by treatment, but it tended $(P=0.11)$ to be affected on $\mathrm{d} 7$. Control cows had $(P=0.04)$ upregulated expression of mRNA for TNFRS1A on d 7 compared with rbST cows (Figure $3)$. Treatment, however, did not affect plasma TNF- $\alpha$ concentrations during the prepartum and postpartum periods $(P \geq 0.20$; Table 3$)$. Hepatic mRNA expression for ICAM1 on $\mathrm{d}-7$ was $(P=0.02)$ affected by treatment, as mRNA expression for ICAM1 was $(P=0.03)$ upregulated by the rbST87.5 treatment compared with the rbST125 treatment (Figure 3). Treatment affected $(P=0.05)$ mRNA expression for ICAM1 on d 7 because control cows had $(P=0.02)$ upregulated expression of mRNA for ICAM1 compared with rbST cows (Figure $3)$. The mRNA expression for $C X C L 1$ on $\mathrm{d}-7$ was not $(P=0.29)$ affected by treatment, but on $\mathrm{d} 7$ treatment tended $(P=0.06)$ to affect mRNA expression for $C X C L 1$ expression because control cows had $(P=0.02)$ upregulated mRNA expression for $C X C L 1$ expression compared with rbST cows (Figure 3$)$. There was no $(P$ $=0.44)$ treatment effect on hepatic mRNA expression for $M Y D 88$ on d -7 . On d 7, however, treatment affected $(P=0.02)$ mRNA expression for $M Y D 88$, as control cows had $(P=0.01)$ upregulated mRNA expression for MYD88 compared with rbST cows (Figure 3). Hepatic mRNA expression for HIF1A tended $(P=0.12)$ to be affected by treatment on $\mathrm{d}-7$, as control cows tended $(P=0.09)$ to have upregulated mRNA expression for HIF1A compared with rbST cows. On d 7, treatment tended $(P=0.07)$ to affect the expression of mRNA for HIF1A as control cows had $(P=0.02)$ upregulated mRNA expression for HIF1A compared with rbST cows (Figure 3). Hepatic mRNA expression for $H P$ was not affected by treatment on $\mathrm{d}-7(P=0.20)$ and $7(P=$ 0.32 ) relative to calving (Table 2 ). Plasma haptoglobin concentrations were not affected by treatment during the prepartum $(P=0.56)$ and postpartum $(P=0.19)$ periods (Table 3$)$. Treatment did not $(P>0.15)$ affect hepatic mRNA expression for CEBPD, JUN, MCSF1, NFKB1, TLR2, TNF, and TNFRSF5 on $\mathrm{d}-7$ and 7 relative to calving (Table 2).

Hepatic mRNA expression for NR3C1 was not $(P=$ 0.17 ) affected by treatment on $d-7$. On $d 7$, treatment tended $(P=0.10)$ to be affect mRNA expression for NR3C1 because rbST cows had $(P=0.04)$ upregulated mRNA expression for NR3C1 than control cows (Table $2)$. Hepatic mRNA expression for $I L 1 R N$ on $\mathrm{d}-7$ was not $(P=0.57)$ affected by treatment but, on $\mathrm{d} 7$, treatment affected $(P=0.05)$ the expression of mRNA for $I L 1 R N$, as control cows had $(P=0.02)$ upregulated
mRNA expression for IL1RN than rbST cows (Figure $3)$. Similarly, treatment did not $(P=0.78)$ affect the mRNA expression for NFKBIA on d -7 , but it tended $(P=0.06)$ to affect the mRNA expression for $N F K$ $B I A$ on d 7 . Control cows had $(P=0.02)$ upregulated mRNA expression for NFKBIA on d 7 compared with rbST cows (Figure 3). Hepatic mRNA expression for SOCS3 did not $(P=0.23)$ differ among treatments on $\mathrm{d}-7$, but it differed $(P<0.01)$ on d 7 . Expression of mRNA for SOCS3 on d 7 was $(P<0.01)$ upregulated in control cows compared with rbST-treated cows (Figure $3)$. Serum cortisol concentrations during the prepartum $(P=0.20)$ and postpartum $(P=0.56)$ periods were not affected by treatment (Table 3 ). Hepatic mRNA expression for $X B P 1$ on $\mathrm{d}-7$ tended $(P=0.07)$ to be affected by treatment because mRNA expression for $X B P 1$ tended $(P=0.08)$ to be upregulated for rbSTtreated cows compared with control cows (Figure 3). On d 7 , treatment affected $(P=0.03)$ mRNA expression for $X B P 1$, as control cows had $(P=0.01)$ upregulated expression of mRNA for XBP1 compared with rbST-treated cows (Figure 3).

\section{DISCUSSION}

Hepatic adaptive responses to NEB during the periparturient period are mediated by the endocrine system through the uncoupling of constituents of the somatotropic axis, such as GH, GH receptors, IGF-1, IGF-1 binding proteins, and insulin (Bauman, 2000; Lucy, 2008). During the transition from late gestation to early lactation, the increase in $\mathrm{GH}$ concentrations enables the shift of nutrients from diet and body stores toward the mammary gland for milk synthesis (Bauman, 2000). A rise in IGF-1 concentration is not observed during this period of elevated GH concentrations because the decreased abundance of hepatic GH receptors, particularly GHR1A, reduces IGF-1 synthesis to prevent a negative feedback of IGF-1 on GH secretion (Rhoads et al., 2004; Lucy, 2008). Although in the subsample of cows used in the current experiment GH concentrations prepartum were not affected by rbST treatment, Silva et al. $(2015,2017)$ demonstrated that weekly treatment of periparturient cows with $125 \mathrm{mg}$ of rbST increased GH concentration prepartum by approximately $30 \%$; this is similar to the numerical increase observed in the current experiment, suggesting that the current experiment may have been underpowered to detect this difference. Nonetheless, prepartum IGF-1 serum concentrations were increased by the rbST125 treatment, in agreement with previous experiments (Silva et al., 2015, 2017). Cows treated with rbST had increased hepatic mRNA expression for GHR, GHR1A, and IGF1 on d -7 relative to calving, 
suggesting that exogenous GH treatment may have increased IGF-1 synthesis through improved hepatic response to GH by increasing GHR1A abundance. Furthermore, treatment of periparturient cows with rbST increased the hepatic mRNA expression for IGFBP3 on $\mathrm{d}-7$ relative to calving. The IGFBP3 forms a complex with the acid-labile $\alpha$-subunit and IGF-1 that prolongs the half-life of IGF-1 and regulates its interaction with cell surface receptors (Rajaram et al., 1997), which may also have increased IGF-1 concentration. Carriquiry et al. (2009) demonstrated increases in hepatic expression of GHR, IGF1, and IGFB3 during early lactation in cows treated with $500 \mathrm{mg}$ of rbST every $10 \mathrm{~d}$ from 12 to $70 \mathrm{~d}$ postpartum, but, to our knowledge, no data to date reported the effects of rbST on hepatic gene expression during the periparturient period.

The somatotropic axis can be regulated by SOCS2, whose mRNA expression in mice's liver is regulated by $\mathrm{GH}$ through the signal transducer and activator of transcription 5B (STAT5B; Davey et al., 2001). Suppressor of cytokine signaling proteins act as part of a negative feedback system to regulate cytokine signaling pathways to attenuate their signal (Hilton et al., 1998). Even though $S T A T 5 B$ expression was not modulated by $\operatorname{rbST}$ treatment in the current experiment, cows treated with rbST had increased hepatic mRNA for SOCS2 7 d postpartum, suggesting that increased postpartum serum GH concentrations in rbST-treated cows may have caused GH-STAT5B-induced upregulation of mRNA for SOCS2 to attenuate excessive GH signaling. Overfed cows challenged intramammarily with LPS between 7 and $14 \mathrm{~d}$ postpartum had a marked decrease in hepatic mRNA for STAT5B and SOCS2, indicative of an exacerbated uncoupling of the somatotropic axis (Graugnard et al., 2013). Taken together, our findings and that of others suggest that treatment of periparturient cows with rbST may have acted directly, modulating SOCS2 hepatic expression, or indirectly, improving the immune function and reducing the incidence of infectious diseases (e.g., metritis; Silva et al., 2015, 2017), to reduce the magnitude of the uncoupling of the somatotropic axis. It is also possible that the rbST treatment of periparturient cows may have attenuated the uncoupling of the somatotropic axis through the upregulation in hepatic mRNA for INSR, which could have led to increased liver responsiveness to insulin. Rhoads et al. (2004) demonstrated that cows subjected to hyperinsulinemic-euglycemic clamps during late pregnancy and early lactation had increased hepatic GHR and GHR1A mRNA expression and plasma IGF-1 concentration, suggesting that insulin may be involved in the recoupling of the somatotropic axis (Lucy, 2008).

Hepatocytes are major targets for GH, which, upon binding to its receptors, activates the Ras-Raf-MEK-
MAPK and JAK-STAT signaling pathways, resulting in the translocation of homodimers and heterodimers (e.g., STAT1, STAT2, STAT3, STAT4, STAT5A, $S T A T 5 B$, and STAT6) to the nucleus to bind to target DNA elements and regulate gene transcription (Zhu et al., 1998). Among other things, GH regulates the mRNA expression for hepatocyte nuclear factors through STAT5 signaling (Costa et al., 2003). Hepatocyte nuclear factor 4, for example, is essential for transcription of $P C K 1$ and $G 6 P C$ genes through the recruitment of the peroxisome proliferator-activated receptor coactivator- $1 \alpha$ protein encoded by the gene PPARGC1A (Rhee et al., 2003). It is interesting that mRNA expression for $H_{4 F} 4$ and PPARGC1A did not differ among treatments, resulting in no changes in G6PC mRNA expression. Hepatic mRNA expression for $P C K 1$, a key enzyme in the conversion of oxaloacetate to phosphoenolpyruvate (Velez and Donkin, 2004), was increased in rbST125 cows 7 d postpartum, indicating that rbST treatment improved hepatic gluconeogenesis. Furthermore, rbST125 cows had increased hepatic mRNA expression for ACOX1 $7 \mathrm{~d}$ postpartum, an enzyme involved in the fatty acid $\beta$-oxidation that may increase production of ATP to support gluconeogenesis and prevent lipid esterification and accumulation in the liver (Aoyama et al., 1994). Sheep liver slices treated with rbST had increased complete fatty acid oxidation to $\mathrm{CO}_{2}$ and decreased rates of fatty acid esterification, sparing ATP for increased rates of gluconeogenesis (Emmison et al., 1991). Although the upregulation of mRNA for PCK1 and ACOX1 were not associated with increased plasma glucose concentrations, we speculate that this was a consequence of the increase in milk yield among rbST-treated cows (Silva et al., 2015).

Culture of hepatocytes in the presence of GH reduced the accumulation of intracellular TAG (Emmison et al., 1991), and lactating cows treated with rbST were less likely to develop fatty liver in spite of rbST-induced lipolysis and influx of fatty acids to the liver (Pocius and Hertlein, 1986). On d -7 relative to calving, cows treated with rbST had increased hepatic mRNA expression for $S C A R B 1$, a receptor for high-density lipoprotein, and for APOA5 and APOB100, apolipoproteins involved in the secretion of very low-density lipoproteins (VLDL) from the liver. We speculate that the upregulation of $A P O A 5$ and APOB100 stimulated the synthesis or secretion of VLDL and activated the lipoprotein lipase in peripheral tissues (Kraja et al., 2010), improving transport of triglycerides from the liver, overall lipid metabolism, and delivery of preformed fatty acids to the mammary gland (Emmison et al., 1991). Furthermore, hepatic mRNA expression for ANGPTL4, an angiopoietin-like protein that prevents fat storage and stimulates fat mobilization, was upregulated by rbST 
treatment on $\mathrm{d}-7$ relative to calving. Upregulation of mRNA expression for ANGPTL4 in calf hepatocytes has been correlated with culture in media containing fatty acid concentrations $>0.6 \mathrm{mmol} / \mathrm{L}$ (Wang et al., 2015). In the current experiment, fatty acid concentrations did not differ among treatments, suggesting that rbST may have acted directly to upregulate mRNA for ANGPTL4 in periparturient cows, as it has in mid-lactation cows (Koltes and Spurlock, 2012). The hepatic expression of mRNA for PPARD, a nuclear receptor activated by fatty acids and associated with lipid accumulation, was downregulated on $\mathrm{d} 7 \mathrm{in}$ rbST cows. The rbST-induced changes in hepatic expression of mRNA for $S C A R B 1$, APOA5, APOB100, ANGPTL4, and PPARD suggests that treatment of periparturient cows with rbST could alter hepatic lipid metabolism to the point of reducing liver TAG accumulation and increasing liver VLDL secretion, which are expected to improve liver health.

In the current experiment, rbST cows had reduced postpartum BHB concentrations compared with control cows. Ketogenesis is associated with the upregulation of mRNA for HMGCLL1, which codifies the 3-hydroxymethyl-3-methylglutaryl-CoA lyase-like 1 enzyme and catalyzes the cleavage of HMGCS2 into acetyl-CoA and acetoacetate (van Dorland et al., 2009). Although we expected that differences in the expression of mRNA for $H M G C L L 1$ would help explain possible differences in BHB concentrations among treatments, mRNA for $H M G C L L 1$ was not detected in the current experiment. Decreased ketogenesis postpartum is associated with reduced hepatic accumulation of TAG (Graugnard et al., 2013). Silva et al. (2015) did not observe differences in hepatic TAG and glycogen contents between rbSTtreated and control cows, but this may have been the consequence of insufficient sample size, as hepatic glycogen content of rbST-treated cows was $75 \%$ greater than control cows. Liver lipidosis develops when the hepatic uptake of fatty acids exceeds its oxidation and secretion as TAG in VLDL by the liver, leading to impaired liver function and incomplete fatty acid oxidation to ketone bodies and causing ketosis (Grummer et al., 2004). In the current experiment, cows treated with rbST had reduced BHB concentration postpartum compared with control cows, which can be a result of improved hepatic fatty acid complete oxidation and VLDL secretion, as explained previously. It is important to note, however, that the effects of rbST treatment of periparturient cows on BHB concentrations have been mixed, with some researchers reporting a positive effect (Putnam et al., 1999; Gulay et al., 2007; Silva et al., 2015) and some reporting a negative effect (Eppard et al., 1996; Gohary et al., 2014; Silva et al., 2017).

In the current experiment, hepatic mRNA expression for proinflammatory genes were upregulated among con- trol cows $7 \mathrm{~d}$ postpartum compared with rbST cows. It is likely that the upregulation of proinflammatory genes among control cows was a consequence of differences in incidence of ketosis and metritis compared with rbSTtreated cows (Silva et al., 2015). A bovine microarray platform used to study hepatic gene networks underlying nutrition-induced ketosis revealed an upregulation of genes and nuclear receptors associated with cytokine signaling and inflammation (Loor et al., 2007). Inflammation can induce lipolysis, glycogenolysis, and hepatic lipid accumulation (Chioléro et al., 1997). Cows injected with recombinant bovine TNF- $\alpha$ had increased liver TAG content and decreased liver mRNA for $G 6 G$ and PCK1 (Bradford et al., 2009). Although plasma TNF- $\alpha$ concentrations were not affected by treatments in the current experiment, control cows had increased hepatic mRNA expression for TNFRSF1A $7 \mathrm{~d}$ postpartum. Liver proliferative response to injury can be initiated by the release of $\mathrm{TNF}-\alpha$, as observed by a $70 \%$ reduction in hepatocyte DNA replication in $T N$ FRSF1A knockout mice (Yamada et al., 1997). Thus, the increased hepatic TNFRSF1A expression exhibited by control cows compared with rbST-treated cows is possibly associated with hepatocyte injury. Treatment of mice with induced hepatic injury with a neutralizing antibody against $C X C L 16$, a chemokine that promotes immune cell infiltration in the liver, reduced hepatic macrophage accumulation and steatosis (Wehr et al., 2014). Control cows had greater mRNA for CXCL1 7 d postpartum, a gene that is translated to a chemokine produced by macrophages and hepatocytes that acts similarly to CXCL16 (Charo and Ransohoff, 2006). In addition, control cows had greater mRNA expression for ICAM1 $7 \mathrm{~d}$ postpartum, a gene that encodes an intercellular adhesion molecule involved in the transmigration of leukocytes into tissues and is upregulated upon cytokine stimulation. These findings suggest that control cows may have been more prone to liver infiltration of immune cells than rbST-treated cows. The transcription factor hypoxia-inducible factor $1-\alpha$ encoded by the gene HIF1A is involved in the inflammation process increasing angiogenesis, cell proliferation, and tissue regeneration (Cramer et al., 2003). Zhang et al. (2015) demonstrated that drug-induced upregulation of HIF1A protein enhances regeneration of lost and damaged tissue in mice after an earhole punch injury. Among control cows, the hepatic mRNA expression for $H I F 1 A$ tended to be and was upregulated -7 and $7 \mathrm{~d}$ relative to calving, respectively, and may be a consequence of increased hepatocyte damage. The expression of the HIF1A gene is regulated by the nuclear factor kappa enhancer in B-cells (NFאB) encoded by the NFKB1 gene. Treatment with rbST did not affect the expression of NFKB1; however, the mRNA expression 
for NFKBIA, an inhibitor of NFKB signaling pathway, was increased in control cows $7 \mathrm{~d}$ postpartum. Taken together, these data suggest that the NFkB signaling cascade was activated in control cows, resulting in greater hepatic HIF1A expression; however, an antiinflammatory response, through the upregulation of $N F K B I A$, was also induced, perhaps to attenuate the hepatic inflammation process.

Liver macrophages, called Kupffer cells, are able to promote fat accumulation in hepatocytes by expressing IL-1 $\beta$ and by binding to IL- 1 receptor type 1 encoded by the gene $I L 1 R$ (Leroux et al., 2012). The mRNA expression for $I L-1 \beta$ and $I L 1 R$ were not evaluated in the current experiment. Nonetheless, the hepatic mRNA expression for IL1RN, an inhibitor of the IL-1 receptor type 1, and $S O C S 3$, a suppressor of cytokine signaling pathways, were upregulated in control cows 7 d postpartum. The activation of IL- 1 receptor type 1 by IL-1 $\beta$ in response to LPS stimulation dysregulates the hepatic lipid and lipoprotein metabolism and increases lipid peroxidation, resulting in the accumulation of oxidized low-density lipoproteins in large lipid droplets in the Kupffer cells (Leroux et al., 2012). Consequently, Kupffer cells are activated and produce high amounts of proinflammatory cytokines and chemokines, mediating the recruitment of leukocytes to the liver (Leroux et al., 2012). We speculate that the greater incidence of metritis among control cows (Silva et al., 2015) might have sensitized Kupffer cells to produce proinflammatory cytokines and chemokines, which in turn may have stimulated the upregulation of anti-inflammatory genes (e.g., IL1RN and SOCS3) to contain the proinflammatory signals. It is also possible that the greater metabolic challenge of control cows resulted in upregulation of $S O C S 3$, as hepatic expression of mRNA for SOCS3 was associated with insulin resistance and steatosis in obese mice (Ueki et al., 2005).

The mRNA expression for MYD88 was greater in control cows than rbST-treated cows $7 \mathrm{~d}$ postpartum. Intramammary challenges with LPS $7 \mathrm{~d}$ postpartum increased the hepatic expression of mRNA for $T N F$, MYD88, and NFKB1 (Graugnard et al., 2013). Therefore, we speculate that the increase in incidence of metritis among control cows (Silva et al., 2015) may have resulted in greater stimulation of toll-like receptors and upregulation of mRNA for MYD88 among control cows. It is important to mention, however, that treatment of periparturient cows with rbST increased PMNL expression of adhesion molecules, phagocytosis, and oxidative burst, increased antibody concentrations, and decreased the incidence of retained placenta and metritis and the concentration of haptoglobin postpartum (Silva et al., 2015, 2017). Thus, rbST treatment may have directly or indirectly modulated the expres- sion of mRNA for genes associated with inflammation and immune responses.

Metabolic disorders and inflammation are linked to oxidative stress and endoplasmic reticulum (ER) stress in periparturient dairy cows (Ringseis et al., 2015). During early lactation the liver is exposed to metabolic and inflammatory challenges, such as fatty acids, TNF- $\alpha$, IL- $1 \beta$, reactive oxygen species, and LPS, which are known inducers of ER stress (Ringseis et al., 2015). Increased mitochondrial lipid flux and exposure to high concentrations of fatty acids disrupt ER membranes and result in the release of stored calcium that contributes to oxidative stress and greatly increase cytoplasmic reactive oxygen species concentrations, resulting in impaired ER protein folding (Wei et al., 2009). Protein misfolding triggers the unfolded protein response, of which the transcription factor X-box binding protein 1 is a critical effector through the regulation of genes involved in ER homeostasis (Yoshida et al., 2001). In addition, the unfolded protein response signaling cascades and inflammatory signaling pathways are tightly linked (Darling and Cook, 2014). The ER stress-induced unfolded protein response is believed to contribute to pathophysiologic conditions of periparturient cows, such as fatty liver, ketosis, and hepatic inflammation (Ringseis et al., 2015). In the current experiment, hepatic mRNA expression for XBP1 was upregulated among control cows, which we speculate to be indicative of a state of oxidative stressed due to inflammation and impaired lipid metabolism as a consequence of the upregulation of mRNA expression for genes related to inflammation and the downregulation of mRNA expression of genes related to lipid oxidation and transport. Graugnard et al. (2013) demonstrated that hepatic mRNA expression for $X B P 1$ was upregulated during early lactation of overfed cows challenged intramammarily with LPS, supporting the theory of a synergistic effect of impaired lipid metabolism and inflammation on oxidative stress response. The positive effects of rbST treatment on hepatic expression of mRNA for genes related to lipid metabolism, inflammation, and oxidative stress during the phase of greatest metabolic and infectious challenges of cows may present an important alternative to reduce the incidence of metabolic diseases.

\section{CONCLUSIONS}

Treatment of periparturient cows with 87.5 and 125 mg of rbST weekly from -21 to $28 \mathrm{~d}$ relative to calving may improve liver health and function and attenuate the decoupling of the somatotropic axis through upregulation of somatotropic axis genes (e.g., GHR and GHR1A), resulting in increased hepatic IGF1 
mRNA and plasma IGF-1 concentration. Furthermore, treatment with rbST may improve glucose and lipid metabolism, through upregulation of transcription of key hepatic enzymes involved in gluconeogenesis and lipid oxidation, and apolipoproteins and lipid receptors responsible for lipid transport and secretion from the liver, resulting in decreased postpartum BHB concentrations among rbST-treated cows. Treatment of periparturient cows with rbST may also prevent postpartum hepatic infiltration of immune cells and hepatocyte injury, demonstrated by the downregulation of mRNA expression for genes associated with inflammation compared with control cows. The results of the current experiment demonstrate that rbST treatment during the periparturient period improves hepatic lipid metabolism and inflammatory status, which may have acted synergistically to decrease hepatic oxidative stress.

\section{ACKNOWLEDGMENTS}

The authors thank the owners, managers, and staff of Emerald II Dairy (Emerald, WI) and CAPES Foundation, Ministry of Education of Brazil (Brasília, BR). Partial funding provided by the HATCH Program, College of Veterinary Population Medicine, University of Minnesota.

\section{REFERENCES}

Andersen, C. L., J. L. Jensen, and T. F. Orntoft. 2004. Normalization of realtime quantitative reverse transcription-PCR data: A model-based variance estimation approach to identify genes suited for normalization, applied to bladder and colon cancer data sets. Cancer Res. 64:5245-5250.

Aoyama, T., K. Tsushima, M. Souri, T. Kamijo, Y. Suzuki, N. Shimozawa, T. Orii, and T. Hashimoto. 1994. Molecular cloning and functional expression of a human peroxisomal acyl-coenzyme A oxidase. Biochem. Biophys. Res. Commun. 198:1113-1118.

Ballou, M. A., R. C. Gomes, S. O. Juchem, and E. J. DePeters. 2009. Effects of dietary supplemental fish oil during the peripartum period on blood metabolites and hepatic fatty acid compositions and total triacylglycerol concentrations of multiparous Holstein cows. J. Dairy Sci. 92:657-669.

Bauman, D. E. 2000. Regulation of nutrient partitioning during lactation: homeostasis and homeorhesis revisited. Page 331 in Ruminant Physiology Digestion, Metabolism, Growth and Reproduction. CABI Publishing, New York, NY.

Bell, A. W., and D. E. Bauman. 1997. Adaptations of glucose metabolism during pregnancy and lactation. J. Mammary Gland Biol. Neoplasia 2:265-278

Boyd, R. D., and D. E. Bauman. 1989. Mechanisms of action for somatotropin in growth. Pages 257-293 in Current Concepts of Animal Growth Regulation. D. R. Campion, G. J. Hausman, R. J. Martin, ed. Plenum, New York, NY.

Bradford, B. J., L. K. Mamedova, J. E. Minton, J. S. Drouillard, and B. J. Johnson. 2009. Daily injection of tumor necrosis factor- $\alpha$ increases hepatic triglycerides and alters transcript abundance of metabolic genes in lactating dairy cattle. J. Nutr. 139:1451-1456.

Carriquiry, M., W. J. Weber, S. C. Fahrenkrug, and B. A. Crooker 2009. Hepatic gene expression in multiparous Holstein cows treat- ed with bovine somatotropin and fed n-3 fatty acids in early lactation. J. Dairy Sci. 92:4889-4900.

Charo, I. F., and R. M. Ransohoff. 2006. The many roles of chemokines and chemokine receptors in inflammation. N. Engl. J. Med. 354:610-621.

Chioléro, R., J. P. Revelly, and L. Tappy. 1997. Energy metabolism in sepsis and injury. Nutrition 13:45S-51S.

Cohick, W. S., K. Plaut, S. J. Sechen, and D. E. Bauman. 1989. Temporal pattern of insulin-like growth factor-I response to exogenous bovine somatotropin in lactating cows. Domest. Anim. Endocrinol 6:263-274.

Costa, R. H., V. V. Kalinichenko, A. L. Holterman, and X. Wang. 2003. Transcription factors in liver development, differentiation, and regeneration. Hepatology 38:1331-1347.

Cramer, T., Y. Yamanishi, B. E. Clausen, I. Förster, R. Pawlinski, N. Mackman, V. H. Haase, R. Jaenisch, M. Corr, V. Nizet, G. S. Firestein, H. P. Gerber, N. Ferrara, and R. S. Johnson. 2003 HIF-1alpha is essential for myeloid cell-mediated inflammation. Cell 112:645-657.

Darling, N. J., and S. J. Cook. 2014. The role of MAPK signaling pathways in the response to endoplasmic reticulum stress. Biochim. Biophys. Acta 1843:2150-2163.

Davey, H. W., T. Xie, M. J. McLachlan, R. J. Wilkins, D. J. Waxman, and D. R. Grattan. 2001. STAT5b is required for GH-induced liver IGF-I gene expression. Endocrinology 142:3836-3841.

Donkin, S. S. 2012. The role of liver metabolism during transition on postpartum health and performance. Pages 97-106 in 2012 Florida Ruminant Nutrition Symposium Proceedings. University of Florida, Gainesville.

Drackley, J. K., T. R. Overton, and G. N. Douglas. 2001. Adaptations of glucose and long-chain fatty acid metabolism in liver of dairy cows during the periparturient period. J. Dairy Sci 84(Suppl.):E100-E112.

Emmison, N., L. Agius, and V. A. Zammit. 1991. Regulation of fatty acid metabolism and gluconeogenesis by growth hormone and insulin in sheep hepatocyte cultures: effects of lactation and pregnancy. Biochem. J. 274:21-26.

Eppard, P. J., J. J. Veenhuizen, W. J. Cole, P. G. Comens-Keller, G. F. Hartnell, R. L. Hintz, L. Munyakazi, P. K. Olsson, R. H. Sorbet, T. C. White, C. A. Baile, R. J. Collier, J. P. Goff, and R. L. Horst. 1996. Effect of bovine somatotropin administered to periparturient dairy cows on the incidence of metabolic disease. J. Dairy Sci. 79:2170-2181.

Farney, J. K., L. K. Mamedova, B. H. Godsey, and B. J. Bradford 2011. Technical note: Validation of an ELISA for measurement of tumor necrosis factor alpha in bovine plasma. J. Dairy Sci. 94:3504-3509.

Ferguson, J. O., D. T. Galligan, and N. Thomsen. 1994. Principal descriptors of body condition score in HO cows. J. Dairy Sci. 77:2695-2703

Gessner, D. K., G. Schlegel, R. Ringseis, F. J. Schwarz, and K. Eder 2014. Up-regulation of endoplasmic reticulum stress induced genes of the unfolded protein response in the liver of periparturient dairy cows. BMC Vet. Res. 10:46.

Gohary, K., S. J. LeBlanc, K. D. Lissemore, M. W. Overton, M. Von Massow, and T. F. Duffield. 2014. Effect of prepartum administration of recombinant bovine somatotropin on health and performance of lactating dairy cows. J. Dairy Sci. 97:6231-6241.

Graugnard, D. E., K. M. Moyes, E. Trevisi, M. J. Khan, D. Keisler, J. K. Drackley, G. Bertoni, and J. J. Loor. 2013. Liver lipid content and inflammametabolic indices in peripartal dairy cows are altered in response to prepartal energy intake and postpartal intrammary inflammatory challenge. J. Dairy Sci. 96:918-935.

Grummer, R. R., D. G. Mashek, and A. Hayirli. 2004. Dry matter intake and energy balance in the transition period. Vet. Clin. North Am. Food Anim. 20:447-470.

Gulay, M. S., A. N. Garcia, M. J. Hayen, C. J. Wilcox, and H. H. Head 2003. Responses of Holstein cows to a low dose of somatotropin (bST) prepartum and postpartum. J. Dairy Sci. 86:3195-3205.

Gulay, M. S., M. J. Hayen, M. Liboni, T. I. Belloso, C. J. Wilcox, and H. H. Head. 2004. Low doses of bovine somatotropin during 
the transition period and early lactation improves milk yield, efficiency of production, and other physiological responses of Holstein cows. J. Dairy Sci. 87:948-960.

Gulay, M. S., M. Liboni, M. J. Hayen, and H. H. Head. 2007. Supplementing Holstein cows with low doses of bovine somatotropin prepartum and postpartum reduces calving-related diseases. J. Dairy Sci. 90:5439-5445.

Hilton, D. J., R. T. Richardson, W. S. Alexander, E. M. Viney, T. A. Willson, N. S. Sprigg, R. Starr, S. E. Nicholson, D. Metcalf, and N. A. Nicola. 1998. Twenty proteins containing a C-terminal SOCS box form five structural classes. Proc. Natl. Acad. Sci. USA 95:114-119.

Hulbert, L. E., J. A. Carroll, N. C. Burdick, R. D. Randel, M. S. Brown, and M. A. Ballou. 2011. Innate immune responses of temperamental and calm cattle after transportation. Vet. Immunol. Immunopathol. 143:66-74.

Koltes, D. A., and D. M. Spurlock. 2012. Adipose tissue angiopoietinlike protein 4 messenger RNA changes with altered energy balance in lactating Holstein cows. Domest. Anim. Endocrinol. 43:307-316.

Kraja, A. T., M. A. Province, R. J. Straka, J. M. Ordovas, I. B. Borecki, and D. K. Arnett. 2010. Fenofibrate and metabolic syndrome. Endocr. Metab. Immune Disord. Drug Targets 10:138-148.

Lalman, D. L., J. E. Williams, B. W. Hess, M. G. Thomas, and D. H. Keisler. 2000. Effect of dietary energy on milk production and metabolic hormones in thin, primiparous beef heifers. J. Anim. Sci. 78:530-538.

Leroux, A., G. Ferrere, V. Godie, F. Cailleux, M. Renoud, F. Gaudin, S. Naveau, S. Prévot, S. Makhzami, G. Perlemuter, and A. Cassard-Doulcier. 2012. Toxic lipids stored by Kupffer cells correlates with their pro-inflammatory phenotype at an early stage of steatohepatitis. J. Hepatol. 57:141-149.

Loor, J. J., R. E. Everts, M. Bionaz, H. M. Dann, D. E. Morin, R. Oliveira, S. L. Rodriguez-Zas, J. K. Drackley, and H. A. Lewin. 2007. Nutrition-induced ketosis alters metabolic and signaling gene networks in liver of periparturient dairy cows. Physiol. Genomics 32:105-116.

Lucy, M. C. 2008. Functional differences in the growth hormone and insulin-like growth factor axis in cattle and pigs: implications for postpartum nutrition and reproduction. Reprod. Domest. Anim. 43(Suppl 2):31-39.

Lupu, F., J. D. Terwilliger, K. Lee, G. V. Segre, and A. Efstratiadis. 2001. Roles of growth hormone and insulin-like growth factor 1 in mouse postnatal growth. Dev. Biol. 229:141-162.

Peel, C. J., and D. E. Bauman. 1987. Somatotropin and lactation. J. Dairy Sci. 70:474-486.

Plaizier, J. C., D. O. Krause, G. N. Gozho, and B. W. McBride. 2008. Subacute ruminal acidosis in dairy cows: The physiological causes, incidence and consequences. Vet. J. 176:21-31.

Pocius, P. A., and J. H. Hertlein. 1986. Effects of in vivo administration of growth hormone on milk production and in vitro hepatic metabolism in dairy cattle. J. Dairy Sci. 69:713-720.

Putnam, D. E., G. A. Varga, and H. M. Dann. 1999. Metabolic and production responses to dietary protein and exogenous somatotropin in late gestation dairy cows. J. Dairy Sci. 82:982-995.

Rajaram, S., D. J. Baylink, and S. Mohan. 1997. Insulin-like growth factor-binding proteins in serum and other biological fluids: Regulation and functions. Endocr. Rev. 18:801-831.

Rhee, J., Y. Inoue, J. C. Yoon, P. Puigserver, M. Fan, F. J. Gonzalez, and B. M. Spiegelman. 2003. Regulation of hepatic fasting response by PPARgamma coactivator- 1alpha (PGC-1): Requirement for hepatocyte nuclear factor 4alpha in gluconeogenesis. Proc. Natl. Acad. Sci. USA 100:4012-4017.

Rhoads, R. P., J. W. Kim, B. J. Leury, L. H. Baumgard, N. Segoale, S. J. Frank, D. E. Bauman, and Y. R. Boisclair. 2004. Insulin increases the abundance of the growth hormone receptor in liver and adipose tissue of periparturient dairy cows. J. Nutr. 134:1020-1027.
Ringseis, R., D. K. Gessner, and K. Eder. 2015. Molecular insights into the mechanisms of liver-associated diseases in early-lactating dairy cows: Hypothetical role of endoplasmic reticulum stress. J. Anim. Physiol. Anim. Nutr. (Berl.) 99:626-645.

Sigl, T., K. Gellrich, H. H. Meyer, M. Kaske, and S. Wiedemann. 2013. Multiparous cows categorized by milk protein concentration and energy-corrected milk yield during early lactation: Metabolism, productivity and effect of a short-term feed restriction. J. Anim. Physiol. Anim. Nutr. (Berl.) 97:278-296.

Silva, P. R. B., K. S. Machado, D. N. Lobão Da Silva, G. N. Moraes, D. H. Keisler, and R. C. Chebel. 2015. Effects of recombinant bovine somatotropin during the periparturient period on innate and adaptive immune responses, systemic inflammation, and metabolism of dairy cows. J. Dairy Sci. 98:4449-4464.

Silva, P. R. B., H. F. Soares, W. D. Braz, G. D. Bombardelli, J. A. Clapper, D. H. Keisler, and R. C. Chebel. 2017. Effects of treatment of periparturient dairy cows with recombinant bovine somatotropin on health and productive and reproductive parameters. J. Dairy Sci. 100:3126-3143. https://doi.org/10.3168/ jds.2016-11737.

Sprecher, D. J., D. E. Hostetler, and J. B. Kaneene. 1997. A lameness scoring system that uses posture and gait to predict dairy cattle reproductive performance. Theriogenology 47:1179-1187.

Ueki, K., T. Kadowaki, and C. R. Kahn. 2005. Role of suppressors of cytokine signaling SOCS-1 and SOCS-3 in hepatic steatosis and the metabolic syndrome. Hepatol. Res. 33:185-192.

van Dorland, H. A., S. Richter, I. Morel, M. G. Doherr, N. Castro, and R. M. Bruckmaier. 2009. Variation in hepatic regulation of metabolism during the dry period and in early lactation in dairy cows. J. Dairy Sci. 92:1924-1940.

Velez, J. C., and S. S. Donkin. 2004. Bovine somatotropin increases hepatic phosphoenolpyruvate carboxykinase mRNA in lactating dairy cows. J. Dairy Sci. 87:1325-1335.

Vels, L., C. M. Rontved, M. Bjerring, and K. L. Ingvartsen. 2009. Cytokine and acute phase protein gene expression in repeated liver biopsies of dairy cows with a lipopolysaccharide-induced mastitis. J. Dairy Sci. 92:922-934.

Wang, J., X. Zhu, Z. W. J. Yao, B. Zhao, and G. Liu. 2015. Nonesterified fatty acids promote expression and secretion of angiopoietin-like protein 4 in calf hepatocytes cultured in vitro. Mol. Cell. Biochem. 401:141-146.

Wehr, A., C. Baeck, F. Ulmer, N. Gassler, K. Hittatiya, T. Luedde, U. P. Neumann, C. Trautwein, and F. Tacke. 2014. Pharmacological inhibition of the chemokine CXCL16 diminishes liver macrophage infiltration and steatohepatitis in chronic hepatic injury. PLoS One 9:e112327.

Wei, Y., D. Wang, C. Gentile, and M. Pagliassotti. 2009. Reduced endoplasmic reticulum luminal calcium links saturated fatty acid mediated endoplasmic reticulum stress and cell death in liver cells. Mol. Cell. Biochem. 331:31-40.

Yamada, Y., I. Kirillova, J. J. Peschon, and N. Fausto. 1997. Initiation of liver growth by tumor necrosis factor: deficient liver regeneration in mice lacking type I tumor necrosis factor receptor. Proc. Natl. Acad. Sci. USA 94:1441-1446.

Yoshida, H., T. Matsui, A. Yamamoto, T. Okada, and K. Mori. 2001. XBP1 mRNA is induced by ATF6 and spliced by IRE1 in response to ER stress to produce a highly active transcription factor. Cell 107:881-891.

Zhang, Y., I. Strehin, K. Bedelbaeva, D. Gourevitch, L. Clark, J. Leferovich, P. B. Messersmith, and E. Heber-Katz. 2015. Druginduced regeneration in adult mice. Sci. Transl. Med. 7:290ra92.

Zhu, T., E. L. K. Goh, and P. E. Lobie. 1998. Growth hormone stimulates the tyrosine phosphorylation and association of P125 focal adhesion kinase (Fak) with Jak2 -Fak is not required for Statmediated transcription. J. Biol. Chem. 273:10682-10689. 